\title{
Examining the Attitudes of Classroom Teachers Towards Sports: Example of Kırşehir Province
}

\author{
Vahit Çiriş $^{1}$ \& Turan Başkonuş ${ }^{2}$ \\ ${ }^{1}$ Kırşehir Ahi Evran University School of Physical Education and Sports, Kırşehir, Turkey \\ ${ }^{2}$ Ministry of Education, Kırşehir, Turkey \\ Correspondence: Vahit Çiriş, Kırşehir Ahi Evran University School of Physical Education and Sports, Kırşehir, \\ Turkey. E-mail: vahit.ciris@ahievran.edu.tr
}

Received: August 11, 2020 Accepted: September 13, 2020 Online Published: September 24, 2020

doi:10.5539/jel.v9n5p248 URL: https://doi.org/10.5539/jel.v9n5p248

\begin{abstract}
The purpose of this research is to determine the attitudes of classroom teachers towards sports. Within this scope, in the first part of this study, it is aimed to describe the attitudes of classroom teachers towards sports. In the second part of the study, it was investigated whether gender, participation in sports activities and years of service differ significantly on the attitudes of classroom teachers towards sports. The screening method was used in this research. The study was carried out with 308 classroom teachers working in Kırşehir. They participated in the study on a volunteer basis. "Personal Information Form" and "The Sports-Oriented Attitude Scale" were used in the data collection process. When testing the research data, a 0.05 significance level was taken. In the analysis of the data, the items related to the sub-problem were grouped and Mann Whitney $U$ and Kruskall Wallis techniques were used together with descriptive statistics such as frequency (f), percent $(\%)$, weighted mean $(\overline{\mathrm{X}})$ and standard deviation (SD). The attitudes of classroom teachers towards sports generally high $(\overline{\mathrm{X}}=4.42)$. While their attitudes towards sports do not differ significantly according to their gender $(\mathrm{U}=10381,500 ; \mathrm{p}>.05)$; it differs significantly according to their participation in sports activities $(U=8686,000 ; p<.05)$ and years of service $\left(\mathrm{X}^{2}=8,364 ; \mathrm{p}<.05\right)$. Research results show that attitudes of classroom teachers towards sports are generally at a high level. However, it was concluded that the attitudes of classroom teachers towards sports differed significantly according to their participation in sports activities and years of service, but did not differ by gender.
\end{abstract}

Keywords: attitude, classroom teacher, sport

\section{Introduction}

It should not be wrong to consider equal the emergence of sport and human history. Because, humans have benefited from movement, sports and physical education to shelter in nature, to hunt for food and drink, to defend themselves against predators, since the first human beings. These movements, which people developed originally to meet their own needs, were got into integrity and were named gymnastics and sports. Sports, which quickly took its place in the history scene, BC., led to the emergence of Olympic games in 776 (Dalgın, 2019). Throughout history, humankind has developed many implementations of sports. Sports, which initially emerged as a means of struggle against nature and other creatures, has been used as a means of entertainment and recreative spending time within the years (Gülüm, 2008; Yorulmaz, 2012). "The whole-body movement that provides physical and mental development of the individual and makes the individual healthy" will be the most popular answer to the question of what sports are (Erdemli, 2012). At this point, it is seen that the concept of sports and physical education are being used interchangeably. In cases where the physical and cognitive development of the individual is the subject, the sports are the other concept that is used equivalent to physical education concept (Görücü, 2007). Muallimoğlu (2003) defined physical education as a discipline to understand the effect that occurs on the individual through activities performed in games, gymnastics, teams and individual sports. Physical education is a phenomenon that changes behavior in the individual (Çelik \& Pulur, 2011) and does this through games, sports and exercises (Demirel, 2003). Physical education and sports can be defined as the whole of the activities (Zengin, 2013) that educate the individual through movement (Demirhan, 2003), give the individual the opportunity to run, jump and move (Nebioğlu, 2006), provide all these in terms of both individual and group dynamics (Çoban \& Ünveren, 2007), develop the individual physically and mentally (Çelik 
\& Pulur, 2011).

Physical education plays an important role in the social development of the individual as well as in the physical development of the individual (Çiriş, 2018). Therefore, sports and physical education are important in primary schools, which are the first step of the individual's learning. Because sports have an important place in an individual at the age of elementary school to discover himself and his environment through movement (Şengül, 2009). The Ministry of National Education considered sports as significant for the development of children in primary schools and provided sports lessons in the curriculum under the name of 17 hours of weekly games and physical activities lessons provided that they are at every level of primary school. These lessons are performed through classroom teachers. Teachers who are seen as role models in learning life and developing attitudes and behaviors of the children towards events have a great impact (Köse \& Demir, 2014). Classroom teachers are the instructors who make the children acquire basic life-skills as well as teach them literacy, four arithmetic operations, social sciences, science, sports and art (Yilmaz, 2017). Attitude is an internal state that includes feelings and thoughts (Başkonuş, 2010). In primary school, the role of classroom teachers is considered to be important for children to develop a positive attitude towards sports and to like sports and include it in their lives. This is important for the classroom teachers, who will be a role model, to give their students the habit of doing sports.

The teachers doing sports have high positive attitudes towards sports (Tortop \& Ocak, 2010; Dalama, 2015). It can be said that the students of teachers who have a positive attitude towards sports (Alemdağ, Öncü, \& Sakallığlu, 2014; Dağdelen, 2015) also have a positive attitude (Şişko \& Demirhan, 2002). In addition, it is observed that classroom teachers not doing sports have low attitude levels towards sports (Güvendi \& Serin, 2019). As revealed by the study results in the literature, the positive or negative attitudes that the classroom teachers will develop towards sports are not only limited to the teachers but also has an impact on their students' attitudes towards sports. Considering this importance of the subject, this study was designed to determine the attitude levels of classroom teachers towards sports and to create solutions for bringing the attitudes of teachers who may have a negative attitude to the condition of positive. Some variables, which are thought to be a factor in the attitudes of classroom teachers towards sports, have been used and answers to the following questions have been sought:

- What is the level of classroom teachers' attitude towards sports?

- Do the attitudes of classroom teachers towards sports differ significantly according to the gender variable?

- Do the attitudes of classroom teachers towards sports differ significantly according to the service year variable?

- Do the attitudes of classroom teachers towards sports differ significantly according to the variable of participation in sports activities?

It is thought that the results consisting of the answers to be given to these questions by the classroom teachers and the suggestions put forward based on these results will contribute to the field.

\section{Method}

\subsection{Participants}

The accessible population of the research is the classroom teachers working in Kırşehir. 329 classroom teachers selected randomly from this population constitute the study sample. 21 of the measurement tools sent to them were not evaluated due to reasons incorrect coding, empty, etc., and the data obtained from a total of 308 classroom teachers were evaluated. Volunteering was sought in filling the measurement tools. It is observed that $44.2 \%(n=136)$ of the study sample is composed of male classroom teachers and $55.8 \%(n=172)$ of female classroom teachers. While $62.3 \%(\mathrm{n}=192)$ of classroom teachers participate in sports activities, $37.7 \%(\mathrm{n}=116)$ do not. While $10.4 \%(n=32)$ of classroom teachers have $1-10$ years of seniority, $43.2 \%(n=133)$ have 21 years or more of seniority.

\subsection{Research Design}

The screening method was used in this research. Screening model studies are a research approach that aims to describe a situation that exists in the past or still as it exists, as it exists (Karasar, 2005). Within this scope, in the first part of this study, it is aimed to describe the attitudes of classroom teachers towards sports. In the second part of the study, the effects of variables of the gender, the participation in sports events and the service year which is considered that it could differ significantly on the attitudes of classroom teachers towards sports were examined. 


\subsection{Data Collection Tools}

In the research, two measurement tools were used in the data collection process. In the first stage, the personal information form (PIF) developed by the researcher was used to determine the personal information of the classroom teachers, whereas in the second stage, the 'The Sports-Oriented Attitude Scale' developed by Koçak (2014) was used to determine the attitudes of the classroom teachers towards sports.

Personal Information Form (PIF). In the form prepared by the researcher, there are some independent variables that are thought to could be effective on the attitudes of classroom teachers towards sports. These variables dealt with demographic information (gender, participation in sports activities and year of service) related to the classroom teachers in general terms, and the data were included in the PIF as classification questions.

The Sports-Oriented Attitude Scale It was developed by Koçak (2014) and consists of 22 items and 3 dimensions. Psychosocial development dimension consists of the items 1, 2, 3, 4, 5, 6, 7, 8, 9, 10, 11 and 12, physical development dimension consists of the items 13,14,15,16, 17 and the mental development dimension consists of the items 18 and 19, 20, 21 and 22. It is a 5-point Likert scale. Items in the scale were organized as fully agree "5" agree " 4 " moderately agree " 3 " slightly agree " 2 " and do not agree " 1 ". In order to test the reliability of the scale, the coefficients of two halves test correlation (Spearman Brown) were examined and this value was found to be 0.83 .

\subsection{Statistical Analysis}

The data obtained was uploaded to the SPSS 20.0 (Statistical Package for Social Sciences) package program for analysis. When testing the research data, a 0.05 significance level was taken. Frequency (f), percentage (\%), weighted average $(\overline{\mathrm{X}})$ and standard deviation $(\mathrm{SD})$ values were used in the analysis of the descriptive data obtained. Before making relational statistical methods, the homogeneity of the data was surveyed and it was examined whether it showed normal distribution. In this process, the relational data analysis process based on the Kolmogorov-Smirnov Test results was shaped. The findings regarding the normal distribution of the data are given in Table 1.

Table 1. Findings about normal distribution

\begin{tabular}{llll}
\hline & \multicolumn{3}{l}{ Kolmogorov-Smirnov } \\
\cline { 2 - 4 } & Statistics & df & p \\
\hline General & .118 & 308 & .000 \\
Psychosocial Development Dimension & .138 & 308 & .000 \\
Physical Development Dimension & .151 & 308 & .000 \\
Mental Development Dimension & .173 & 308 & .000 \\
\hline
\end{tabular}

In line with these results, nonparametric hypothesis tests were used in the analysis of the research data. Within this scope, Mann Whitney $U$ test was used to examine attitudes of the teachers towards sports according to binary porous variables (gender and participation) and Kruskall Wallis test techniques were used to analyze according to three or more porous variables (service year). The answers given by the classroom teachers for the items in the scale are of the five-point Likert type and the formula " $a=$ Range/Number of Groups to be Performed" was used to determine the group value range of the evaluation scale (Taşdemir, 2003). Accordingly, the evaluation scale is as follows:

Table 2. Grading of the scales, weight qualification groups given

\begin{tabular}{|c|c|c|}
\hline \multirow[b]{2}{*}{ Given Weight } & The Sports-Oriented Attitude Scale & \multirow[b]{2}{*}{ Limit } \\
\hline & Qualification group & \\
\hline 5 & Fully Agree & $4.20-5.00$ \\
\hline 4 & Agree & $3.40-4.19$ \\
\hline 3 & Moderately Agree & $2.60-3.39$ \\
\hline 2 & Slightly Agree & $1.80-2.59$ \\
\hline 1 & Do Not Agree & $1-1.79$ \\
\hline
\end{tabular}




\section{Results}

\subsection{Findings Related to Attitudes of Classroom Teachers Towards Sports}

Table 3. Attitudes of classroom teachers towards sports

\begin{tabular}{lllll}
\hline & $\overline{\boldsymbol{X}}$ & SD & Mdn & Level \\
\hline GENERAL & 4.42 & .482 & 4.45 & Fully Agree \\
Psychosocial Development Dimension & 4.44 & .509 & 4.50 & Fully Agree \\
Physical Development Dimension & 4.46 & .500 & 4.50 & Fully Agree \\
Mental Development Dimension & 4.31 & .629 & 4.37 & Fully Agree \\
\hline
\end{tabular}

When Table 3 is analyzed, the attitudes of classroom teachers towards sports are generally high $(\overline{\mathrm{X}}=4.42$; Mdn $=4.45$ ) (fully agree). When the sub-dimensions are examined, attitudes of classroom teachers are high in the psychosocial development dimension $(\overline{\mathrm{X}}=4.44$; Mdn $=4.50)$, physical development dimension $(\overline{\mathrm{X}}=4.46$; Mdn $=4.50)$ and mental development dimension $(\overline{\mathrm{X}}=4.31$ : $\mathrm{Mdn}=4.37)$. This shows that classroom teachers have a positive attitude towards sports.

\subsection{Relational Findings Related to Attitudes of Classroom Teachers Towards Sports}

Table 4. Mann Whitney U test results on the attitudes of classroom teachers towards sports according to their gender

\begin{tabular}{|c|c|c|c|c|c|c|c|c|}
\hline & Gender & $\mathbf{N}$ & Mdn & Mean Rank & Sum of Ranks & $\mathbf{U}$ & $\mathbf{Z}$ & $\mathbf{p}$ \\
\hline \multirow[t]{2}{*}{ General } & Male & 136 & 4.52 & 164.17 & 22326.50 & 10381.500 & -1.699 & .089 \\
\hline & Female & 172 & 4.45 & 146.86 & 25259.50 & & & \\
\hline \multirow[t]{2}{*}{ Psychosocial Development } & Male & 136 & 4.42 & 166.11 & 22591.00 & 10117.000 & -2.052 & $.040 *$ \\
\hline & Female & 172 & 4.67 & 145.32 & 24995.00 & & & \\
\hline \multirow[t]{2}{*}{ Physical Development } & Male & 136 & 4.50 & 155.04 & 21085.50 & 11622.500 & -.096 & .923 \\
\hline & Female & 172 & 4.50 & 154.07 & 26500.50 & & & \\
\hline \multirow[t]{2}{*}{ Mental Development } & Male & 136 & 4.50 & 163.02 & 22170.50 & 10537.500 & -1.529 & .126 \\
\hline & Female & 172 & 4.25 & 147.76 & 25415.50 & & & \\
\hline
\end{tabular}

Note. ${ }^{*} \mathrm{p}<0.05$

When Table 4 is analyzed, it is seen that the mean rank of male teachers $(\overline{\mathrm{X}}=164.17$; $\mathrm{Mdn}=4.52)$ is higher than the mean rank of female teachers $(\overline{\mathrm{X}}=146.86$; $\mathrm{Mdn}=4.45)$ across the scale. Also, in all sub-dimensions, the mean rank of male teachers is high.

In the results of the Mann Whitney U test conducted to determine whether teachers' attitudes towards sports differ significantly according to their gender, it is seen that the mean differences between the groups were not statistically significant across the scale $(U=10381.500 ; p>.05)$, but they were significant in the dimension of psychosocial development $(\mathrm{U}=10117.000 ; \mathrm{p}<.05)$.

Table 5. Mann Whitney $U$ test results regarding the attitudes of classroom teachers towards sports according to their participation in sports activities

\begin{tabular}{lllllllll}
\hline & Participation in Sports Events & N & Mdn & Mean Rank & Sum of Ranks & U & Z & p \\
\hline General & Participate & 192 & 4.59 & 167.26 & 32114.00 & 8686.000 & -3.246 & $.001^{*}$ \\
& Do Not Participate & 116 & 4.36 & 133.38 & 15472.00 & & & \\
Psychosocial & Participate & 192 & 4.67 & 166.90 & 32045.00 & 8755.000 & -3.170 & $.002 *$ \\
Development & Do Not Participate & 116 & 4.33 & 133.97 & 15541.00 & & & \\
Physical & Participate & 192 & 4.67 & 164.45 & 31573.50 & 9226.500 & -2.563 & $.010^{*}$ \\
Development & Do Not Participate & 116 & 4.41 & 138.04 & 16012.50 & & \\
Mental & Participate & 192 & 4.50 & 165.33 & 31743.00 & 9057.000 & -2.812 & $.005^{*}$ \\
Development & Do Not Participate & 116 & 4.00 & 136.58 & 15843.00 & & & \\
\hline Note * $<0.05$ & & & & & & & &
\end{tabular}

When Table 5 is examined, it is observed that the mean rank of the teachers who responded as 'Participate' to sports activities $(\overline{\mathrm{X}}=167.26)$ across the scale is higher than those who responded as 'Do Not Participate' $(\overline{\mathrm{X}}=$ 
133.38). Also, it is seen that the mean rank of teachers who responded as 'Participate' to sports activities in all sub-dimensions is high.

In the results of the Mann Whitney $U$ test conducted to determine whether teachers' attitudes towards sports differ significantly according to their participation in sports activities, it is observed the mean differences between groups are statistically significant across the scale $(U=8686.000 ; p<.05)$ and in all sub-dimensions ( $p$ $<.05)$. This finding shows that teachers participating in sports activities have higher attitudes towards sports.

Table 6. Kruskall Wallis test results regarding the attitudes of classroom teachers towards sports according to their years of service

\begin{tabular}{|c|c|c|c|c|c|c|c|c|}
\hline & Service Year & $\mathbf{N}$ & Mdn & Mean Rank & Chi square & sd & $\mathbf{p}$ & Source of the Difference \\
\hline \multirow[t]{6}{*}{ GENERAL } & ${ }^{1} 1-10$ years & 32 & 4.36 & 129.80 & 8.364 & 3 & $.039 *$ & $2>1$ \\
\hline & & & & & & & & $4>2$ \\
\hline & & & & & & & & $3>$ \\
\hline & ${ }^{2} 11-15$ years & 90 & 4.59 & 166.90 & & & & \\
\hline & ${ }^{3} 16-20$ years & 53 & 4.41 & 131.98 & & & & \\
\hline & ${ }^{4} 21$ years and more & 133 & 4.55 & 161.03 & & & & \\
\hline \multirow{5}{*}{$\begin{array}{l}\text { Psychosocial } \\
\text { Development }\end{array}$} & ${ }^{1} 1-10$ years & 32 & 4.33 & 130.67 & 8.554 & 3 & $.036^{*}$ & $4>3$ \\
\hline & & & & & & & & $3>2$ \\
\hline & ${ }^{2} 11-15$ years & 90 & 4.58 & 165.35 & & & & \\
\hline & ${ }^{3} 16-20$ years & 53 & 4.33 & 130.79 & & & & \\
\hline & ${ }^{4} 21$ years and more & 133 & 4.67 & 162.34 & & & & \\
\hline \multirow{4}{*}{$\begin{array}{l}\text { Physical } \\
\text { Development }\end{array}$} & $1-10$ years & 32 & 4.50 & 139.25 & 7.734 & 3 & .052 & \\
\hline & $11-15$ years & 90 & 4.67 & 171.39 & & & & \\
\hline & $16-20$ years & 53 & 4.33 & 132.31 & & & & \\
\hline & 21 years and more & 133 & 4.50 & 155.58 & & & & \\
\hline \multirow{4}{*}{$\begin{array}{l}\text { Mental } \\
\text { Development }\end{array}$} & $1-10$ years & 32 & 4.00 & 126.98 & 6.466 & 3 & .091 & \\
\hline & $11-15$ years & 90 & 4.50 & 161.32 & & & & \\
\hline & $16-20$ years & 53 & 4.25 & 139.47 & & & & \\
\hline & 21 years and more & 133 & 4.50 & 162.50 & & & & \\
\hline
\end{tabular}

Note. ${ }^{*} \mathrm{p}<0.05$.

When Table 6 is examined, in the results of Kruskall Wallis conducted to determine whether teachers' attitudes towards sports differ significantly according to their years of service, it is observed that the mean differences between groups were statistically significant across the scale $\left(\mathrm{X}^{2}=8.364 ; \mathrm{p}<.05\right)$ and in the sub-dimension of psychosocial development $\left(\mathrm{X}^{2}=8.554 ; \mathrm{p}<.05\right)$. The significant difference was in favor of the premiers between 11-15 years of service teachers and 1-10 years of teachers, between teachers with 21 or more years of service and teachers with 11-15 years of service and between teachers with 16-20 years of service and teachers with 11-15 years of service across the scale; whereas it was in favor of the premiers between teachers with 21 or more years of service and teachers with 16-20 years of service and between teachers with 16-20 years of service and teachers with 11-15 years of service in the dimension of psychosocial development.

This finding shows that the year of service is an effective variable on teachers' attitudes towards sports, and the attitudes of teachers with a service year of 21 years and more are at the highest level.

\section{Discussion}

Attitudes of the classroom teachers towards sports are generally at a high level. Attitudes of the classroom teachers are at a high level in terms of psychosocial development, physical development and mental development. Classroom teachers have a positive attitude towards sports. In the study that Arslan and Altay (2008) examined the attitudes and opinions of classroom teachers towards physical education lesson, they found positive and high attitudes of them towards physical education lesson. In addition, Gültekin, Atalay and Ay (2014) concluded that classroom teachers' views on sports are positive. Along with these studies, there are studies in the literature that conclude that classroom teachers have a positive attitude towards sports (Alemdağ et al., 2014; Matanin \& Collier, 2003; Webster, Monsma, \& Erwin, 2010; Xiang, Lowy, \& McBride, 2002). In similar studies in the literature, some studies find that the classroom teachers develop negative attitudes towards sports for some reasons (physical conditions, lack of a gym, lack of sports-specific activity knowledge) (Bozdemir, Çimen, Kaya, \& Demir, 2015; Morgan \& Hensen, 2010; Pehlivan, Dönmez, \& Yaşat, 2005; Trust \& Yildiz, 2013). It is considered that the teachers, who have a negative attitude towards sports among classroom 
teachers, could not acquire sufficient field knowledge during their undergraduate education, and their attitudes will change positively with the improvement of physical conditions. When these conditions are met, it can be said that the attitudes of the students they train will be positive and the society will spread the sport to every stage of their lives, thanks to teacher attitudes that will change in parallel with the study results. As a result of this study, it can be said that the students they will raise will love the sport and even form a basis for raising successful athletes worldwide among these students, as a result of the positive attitude of the classroom teachers.

The attitudes of classroom teachers towards sports did not differ significantly across the scale. There was a significant difference in the dimension of psychosocial development by gender. It was concluded that the attitudes of female teachers are higher in the psychosocial development dimension. In their study with classroom teachers, Oncu and Cihan (2012) found that gender factor is not a factor in teachers' attitudes towards sports, but the mean rank of female teachers is higher than the mean of male teachers. Depending on this difference between means, it can be said that women have a more positive attitude compared to male teachers. Yavrucu and Çoknaz (2016) found that the mean rank is in favor of women in their classroom teachers' attitudes towards sports. In their study, Bozdemir, Çimen, Kaya and Demir (2015) found that gender was not a factor in the attitude of classroom teachers towards sports, but the difference was in favor of men on the mean rank.

The attitudes of classroom teachers towards sports differ significantly according to their participation in sports activities across the scale and all sub-dimensions. It was concluded that the teachers participating in sports activities had higher attitudes towards sports. In their study, Alemdağ, Öncü and Sakallığlu (2014) found that the attitudes of prospective classroom teachers doing sports towards sports differ significantly compared to those who do not do it. However, unlike the research results, Oncu and Cihan (2012) found that the sports status of teachers does not make a significant difference on the attitude towards sports. Based on the conclusion that the teachers who do sports have a positive attitude, it can be stated that the teachers' gaining the habit of doing sports will contribute to the raising of generations that love and do sports.

Service years showed a significant difference on the attitudes of classroom teachers towards sports across the scale and in the dimension of psychosocial development. This result showed that the service year is an effective variable on the attitudes of teachers towards sports and the attitudes of teachers with a service year of 21 years and more are at the highest level. In the study that Arslan and Altay (2008) measured their classroom teachers' attitude levels towards sports, they found that teachers with seniority between 16-20 years had a higher positive attitude compared to teachers with less seniority. Bozdemir, Çimen, Kaya and Demir (2015) found that the seniority status of classroom teachers is not a factor in their attitudes towards sports, but the mean rank of teachers with high seniority is higher than other teachers. Yavrucu and Çoknaz (2016) found that the seniority variable was not a factor in the attitudes of the classroom teachers towards sports and the difference in the mean rank was in favor of teachers with seniority 11-15 years. These results show that as the year of service of the classroom teachers increases, the positive attitude levels towards sports also increase.

The classroom teacher's role as being in the first stage of education has a critical role in children's life. The findings showed that generally, the teachers had a positive attitude towards sport participation. This finding may imply that the teachers' positive and high level of attitude will contribute to helping children like lifelong sport participation. The teachers' participation in physical activities/sport activities positively influences their attitude towards sport. To maintain this positive influence, it is recommended that school managers/directors organize more physical activities. It was observed that the teachers with 21 and above years of service had the most positive attitudes towards sport participation. Therefore, opportunities for teachers from different years of experience may be provided for effective opinion exchange. This may help comparably new teachers change their attitudes positively towards sport participation. Gender was not found to be an influential factor in the teachers' attitudes towards sport. Even so, MOE may still contribute to teachers' attitude towards sports participation by organizing sport competitions for teachers from different genders.

\section{References}

Alemdağ, S., Öncü, E., \& Sakallığlu, F. (2014). Sınıf öğretmeni adaylarının beden eğitimi dersine yönelik tutum ve öz-yeterlikleri. Abant İzzet Baysal Üniversitesi Eğitim Fakültesi Dergisi, 14(2), 45-60. https://doi.org/10.17240/aibuefd.2014.14.2-5000091527

Arslan, Y., \& Altay, F. (2008). Sınıf öğretmenlerinin beden eğitimi ders programı ve ders uygulamalarına ilişkin görüşleri. Spor Bilimleri Dergisi, 19(2), 63-79.

Atalay, N., Yusuf, A. Y., \& Gültekin, M. (2014). İlköğretimde serbest etkinliklere yönelik sınıf öğretmeni ve öğrenci görüşleri. Kastamonu Ĕ̈itim Dergisi, 22(2), 419-437. 
Başkonuş, T. (2020). Ortaöğretim öğrencilerinin spora yönelik tutumlarının bazı değişkenlere göre incelenmesi (Kırşehir ili örneği). Ahi Evran Üniversitesi Sosyal Bilimler Enstitüsü Dergisi, 6(2), 365-376. https://doi.org/10.31592/aeusbed.730674

Bozdemir, R., Çimen, Z., Kaya, M., \& Demir, O. (2015). Sınıf öğretmenlerinin beden eğitimi ve spor dersinde karşılaş̧ıkları problemler (Tokat İli Örneği). Uluslararası Türk Ĕ̆itim Bilimleri Dergisi, 5, 221-234.

Büyüköztürk, Ş. (2014). Sosyal bilimler için veri analizi el kitabı (20. Bask1). Ankara: Pegem Akademi.

Çelik, Z., \& Pulur, A. (2011). Attitudes of secondary school students toward physical education and sports. Yüzüncü Yll University Faculty of Education Journal, Special Issue, 115(121).

Çiriş, V. (2018). 11. ve 12. sınıf ögrrencilerinin sosyal beceri düzeylerinin liderlik özelliklerine etkisinin spor yapma durumu açısından incelenmesi. Yayımlanmamış doktora tezi, Sakarya Üniversitesi, Eğitim Bilimleri Enstitüsü, Sakarya.

Çoban, B., \& Ünveren, A. (2007). Beden eğitimi ve oyun öğretimi. Ankara: Nobel.

Dalaman, O. (2015). Sınıf öğretmeni adaylarının beden eğitimi ve oyun öğretimi dersine yönelik tutumlarının değişik faktörlerce incelenmesi. Mehmet Akif Ersoy Üniversitesi Eğitim Fakültesi Dergisi, 1(36), 59-71.

Dalgın, İ. (2019). Özel ve devlet liseleri ögrrencilerinin beden eğitimi ve spor dersine ilişkin tutumları. Yayımlanmamış yüksek lisans tezi, İstanbul Gelişim Üniversitesi, Sağlık Bilimleri Enstitüsü, İstanbul.

Demirel, Ö. (2003). Kuramdan uygulamaya eğitimde program geliştirme. Ankara: Pegema Yayıncılık.

Erdemli, A. (2012). Spor nedir? Ne değildir? Din ve Hayat, 17, 18-22.

Erhan, S. E. (2009). Doğu anadolu bölgesi il merkezlerinde beden ĕgitimi dersinin işlenebilirliği, beden eğitimi ögretmenlerinin sorunları ve bunların ögrenci tutumları üzerine etkisi. Yayınlanmamış doktora tezi, Gazi Üniversitesi, Ankara.

Görücü, A. (2007). İlköğretim 7. sınlf beden eğitimi derslerinde işbirliğine dayalı öğrenim destekli çoklu zekâ kuramı uygulamalarının ögrencilerin performans, tutum ve ögrenilenlerin kalıcllı̆̆ına etkisi. Yayımlanmamış doktora tezi, Selçuk Üniversitesi, Sosyal Bilimler Enstitüsü, Konya.

Gülüm, V. (2008). Adana ilindeki beden eğitimi beden eğitimi öğretmenlerinin ilköğretim okullarında uygulanmakta olan beden ĕgitimi ögretim programına yönelik görüşlerinin değerlendirilmesi. Yayımlanmamış yüksek lisans tezi, Çukurova Üniversitesi, Sağlık Bilimleri Enstitüsü, Adana.

Güvendi, B., \& Serin, H. (2019). Sınıf öğretmenliği adaylarının oyun ve fiziksel etkinlikler dersine yönelik tutumları ile fiziksel aktiviteye katılım motivasyonlarının incelenmesi. Elektronik Sosyal Bilimler Dergisi, 18(72), 1957-1968. https://doi.org/10.17755/esosder.573789

Karasar, N. (2005). Bilimsel araştırma yöntemi. Ankara: Nobel.

Koçak, F. (2014). Üniversite öğrencilerinin spora yönelik tutumları: Bir ölçek geliştirme çalışması. Ankara Üniversitesi Spor Bil Fak, 12(1), 59-69. https://doi.org/10.1501/Sporm_0000000254

Köse, M., \& Demir, E. (2014). Öğretmenlerin rol modelliği hakkında öğrenci görüşleri. International Journal of Social and Economic Sciences, 4(1), 08-18.

Matanin, M., \& Collier, C. (2003). Longitudinal analysis of preservice teachers' beliefs about teaching physical education. Journal of Teaching In Physical Education, 22(2), 153-168. https://doi.org/10.1123/jtpe.22.2.153

Morgan, P., \& Hansen, V. (2007). Recommendations to improve primary school physical education: classroom teachers' perspective. The Journal of Educational Research, 101(2), 99-108. https://doi.org/10.3200/JOER.101.2.99-112

Muallimoğlu, N. (2003). Çocuklara ve gençlere beden eğitimi. İstanbul: Avcıol Basım Yayım.

Nebioğlu, D. (2006). Beden eğitimi dersi genel esasları ve planlaması denetimi (2. Baskı). Ankara: Nobel Yayın Dağıtım.

Öncü, E., \& Cihan, H. (2012). Sınıf öğretmeni adayları için beden eğitimi dersi tutum ölçeğinin geliştirilmesi. Dicle Üniversitesi Ziya Gökalp Eğitim Fakültesi Dergisi, 18, 31-47.

Pehlivan, Z., Dönmez, B., \& Yaşat, H. (2005). Sinıf öğretmenlerinin beden eğitimi dersine yönelik görüşleri. Gazi Beden Eğitimi ve Spor Bilimleri Dergisi, 10(3), 51-62.

Şengül, Y. (2016). Sinıf düzeylerine göre ortaokul ve lise ögrencilerinin beden eğitimi yatkınlıklarının incelenmesi. Yayınlanmamış yüksek lisans tezi, Karadeniz Teknik Üniversitesi, Eğitim Bilimleri Enstitüsü, 
Trabzon.

Şişko, M., \& Demirhan, G. (2002). İlköğretim okulları ve liselerde öğrenim gören kız ve erkek öğrencilerin beden eğitimi ve spor dersine ilişkin tutumları. Hacettepe Üniversitesi Eğitim Fakültesi Dergisi, 23(23).

Taşdemir, M. (2003). Eğitimde planlama ve değerlendirme (2. Baskı). Ankara: Ocak Yayınevi.

Tortop, Y., \& Ocak, Y. (2010). Sınıf öğretmenlerinin eğitsel oyun uygulamalarına yönelik görüşlerinin incelenmesi. Spor ve Performans Araştırmaları Dergisi, 1(1), 14-22.

Webster, C., Monsma, E., \& Erwin, H. (2010). The role of biographical characteristics in preservice classroom teachers' school physical activity promotion attitudes. Journal of Teaching in Physical Education, 29(4), 358-377. https://doi.org/10.1123/jtpe.29.4.358

Xiang, P., Lowy, S., \& Mcbride, R. (2002). The impact of a field-based elementary physical education methods course on preservice classroom teachers' beliefs. Journal of Teaching In Physical Education, 21(2), 145-161. https://doi.org/10.1123/jtpe.21.2.145

Yıldız, Ö., \& Güven, Ö. (2014). Sinıf öğretmenlerinin oyun ve fizikî etkinlikler dersinden beklentileri. Kastamonu Ĕ̈itim Dergisi, 22(2), 525-538.

Yilmaz, N. Y. (2018). Students and Teachers' Metaphors about Classroom Teachers. Journal of Education and Learning, 7(1), 245-257. https://doi.org/10.5539/jel.v7n1p245

Yorulmazlar, M. (2012). Tarihi ve genel anlamiyla spor. Din ve Hayat, 17, 4-10. https://doi.org/10.1501/Sporm_0000000216

Yuvacı, H., \& Çoknaz, H. (2016). Sınıf ve beden eğitimi öğretmenliği mezunu beden eğitimi öğretmenlerinin beden eğitimi öğretmenliği mesleğine yönelik tutumlarının karşılaştııılması. CBÜ Beden Eğitimi ve Spor Bilimleri Dergisi, 11(1), 24-36.

Zengin, S. (2013). Çocuk ve gençlik merkezlerinde hizmet alan 12-18 yaş arası erkek çocukların beden eğitimi ve spor dersine ilişkin tutum düzeyleri ile benlik saygılarının incelenmesi. Yayımlanmamış yüksek lisans tezi, Sakarya Üniversitesi, Eğitim Bilimleri Enstitüsü, Sakarya.

\section{Copyrights}

Copyright for this article is retained by the author, with first publication rights granted to the journal.

This is an open-access article distributed under the terms and conditions of the Creative Commons Attribution license (http://creativecommons.org/licenses/by/4.0/). 